\title{
The use of GPR to image three-dimensional (3-D) turbidite channel architecture in the Carboniferous Ross Formation, County Clare, western Ireland
}

\author{
J. K. PRINGLE, J. D. CLARK, A. R. WESTERMAN \& A. R. GARDINER \\ Institute of Petroleum Engineering, Heriot-Watt University, Edinburgh EH14 4AS, UK (e- \\ mail: jamie.pringle@pet.hw.ac.uk)
}

\begin{abstract}
Petroleum reservoir models are currently built from two-dimensional (2-D) information. An understanding of both the large-scale and internal three-dimensional (3-D) architecture of turbidite channel deposits is important for both hydrocarbon exploration and production. A ground penetrating radar (GPR) survey was undertaken on a study site exposing Upper Carboniferous Ross Formation deposits in western Ireland. Both channel margins and intrachannel fill were imaged in 3-D. Constant-offset, 2-D reflection sections were calibrated by vertical radar profiles. GPR data were integrated with sedimentary and survey data to produce a 3-D model of the study site.
\end{abstract}

In petroleum reservoirs, highly detailed, downborehole information constrains near-well geology, but only a very small amount of the reservoir is sampled. Where spacing between wells is relatively large (typical values in the North Sea being $\sim 1000 \mathrm{~m}$, Henson pers. comm.), the inter-well volume is poorly understood. Conventional seismic datasets over reservoirs can identify large-scale sedimentary features, such as 15-25 m-thick sand bodies observed on moderate-quality twodimensional (2-D) seismic lines (Weber 1993). Kolla et al. (2001) detailed how high-resolution, closely spaced three-dimensional (3-D) seismic surveys of Tertiary deposits offshore of Angola could resolve sinuous turbidite channels in 3-D. However, while seismic datasets usually cover the whole reservoir, their low resolution has been a limiting factor in interpreting internal architectures, which can prove barriers to reservoir flow, especially laterally (Arnot et al. 1997).

Studies of outcrops of analogous reservoir rocks can provide quantitative data on the inter-well volumes, which can then be used to populate reservoir models (e.g. Stephens et al. 2001). Outcrop analogue studies generally involve detailed analysis of well-exposed 2-D, planar-like cliff-faces (methodology summarized in Arnot \& Lewis, 1997). Subsequent measurements obtained have to be manipulated to account for the problem of esti- mating 'partial' geometries of architectures bigger than the outcrop itself, a major drawback when using outcrops. Geehan (1993) and Geehan and Underwood (1993) presented a mathematical solution by measuring 'complete' bed lengths, observable in outcrops, and mathematically calculating the most probable 'partial' bed lengths. Visser and Chessa (2000) produce a refinement of this method, removing outcrop length as a factor, based on conditional probability theory.

While typical outcrop exposures allow detailed characterization of 2-D vertical sections through channel-fill deposits, they rarely provide data on the detailed planform architecture. The representivity of a single outcrop is difficult to judge; therefore current models are built either using appropriate subsets of a representative outcrop analogue, or using several analogues to assess sensitivity of the model to the input data (e.g. Beauboeuf et al. 2000). A major problem is the uncertainty in characterizing 3-D volume. 2-D outcrop exposures have been used to generate geostatistics for modelling, but shale-horizon lengths exposed in planar outcrops, for example, do not fully reflect shale distributions, since they may be influenced by the outcrop shape and orientation (Weber 1986). Even if exposures are exceptional and palaeocurrent direction can be inferred (Fig. 1a), the 3-D distributions cannot be known with any certainty (Fig. $1 b \& c$ ). 
(a)

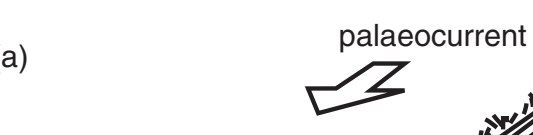

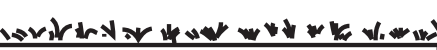
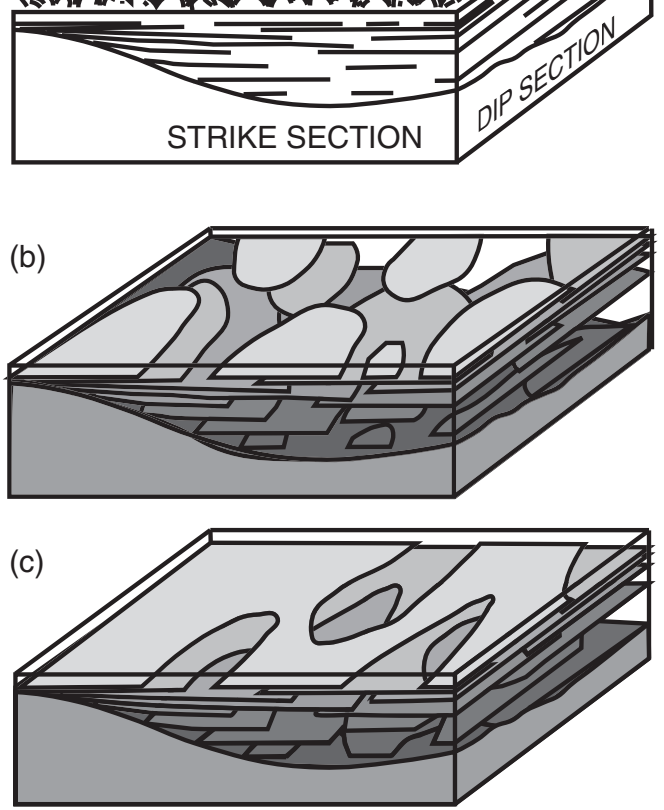

Fig. 1. The schematic diagram illustrates the difficulty in creating 3-D models from 2-D outcrop data, in this case of a turbidite channel fill. Both (b) showing elliptical shale units and (c) showing elliptical amalgamation surfaces, cutting through continuous shale horizons, honour the observed shale lengths exposed on the strike- and dipsections of the outcrop shown in (a). (From Stephen et al. 2001).

Research has been undertaken by other researchers (Bryant et al. 2000; Xu et al. 2000) to create 3-D digital models of outcrops. Recent research at Heriot-Watt University has obtained 3D geometries from outcrop analogue sites (Pringle et al. 2000). Our technique combines detailed sedimentary field $\operatorname{logs}$ with GPR data and digital photogrammetry products. Datasets are integrated to form a digital 3-D outcrop model.

Digital outcrop model techniques were developed in studies on Ordovician turbidites in the Scottish Borders and on Carboniferous turbidites in Derbyshire, UK. This paper introduces a study of the Carboniferous Ross Formation, County Clare, Ireland, an internationally recognized turbidite outcrop analogue site. The aims of this research are two-fold: (1) to create digital 3-D volumetric models of the study site, and (2) to image intrachannel stratal patterns in 3-D. Resulting models can then be analysed to provide 3-D quantitative data for reservoir modellers and used as reference for reservoirs with similar depositional units.

\section{Carboniferous Ross Formation}

The Carboniferous (Namurian) Ross Formation represents a thick accumulation of sandstones and shales forming the early fill of the Western Irish Namurian Basin (Collinson 1991). The basin shows a systematic progradational fill from basinal shales (Clare Shales) to deep-water shales and turbidites (Ross Formation), to chaotic slope deposits (Gull Island Formation) and shallow-water upward-coarsening deltaic sequences (Central Clare Group). Figure 2 shows the stratigraphic column.

The deep-water facies of the Ross Formation are interpreted as having been deposited in front of a major delta system, similar in size and character to the delta system that deposited the overlying Central Clare Group (Collinson 1991). The Ross Formation is very well exposed in coastal sections around the Loop Head peninsula (Fig. 3). Here, the formation is $380 \mathrm{~m}$ thick and consists of $75 \%$ sandstone, but rapidly thins to the north and south. North of the Loop Head peninsula, near the Cliffs of Moher, the Ross Formation forms only part of a $12 \mathrm{~m}$ succession of black shales. Within these shales, and within discrete shale horizons of the turbidite sequence, Goniatites of $\mathrm{H}$ to $\mathrm{R} 1$ age have been identified, which can be used to correlate outcrops across the basin (Hodson 1954). Palaeocurrents in the Ross Formation show that sediment was largely sourced from the southwest.

The sandstone depositional units consist predominantly of sheet-like turbidites formed within laterally extensive, layered or amalgamated sandrich units. Interbedded within these sheet sandstones are erosional, small-scale channels, typically 100-500 m wide and 5-15 m deep. These channels have been interpreted as being deposited from laterally shifting sediment sources from deltaic and submarine slopes (Elliott 2000a). Other features of interest include extensive slides with large slump folds, spectacular, large, flute-shaped scours, sand volcanoes and small-scale sandstone dykes. Elliott (2000b) has suggested that the 'megaflutes' occur in specific distributions and may be the site of turbidite channel initiation.

\section{Bridges of Ross study site}

Several turbidite channels with inclined beds comprising alternations of mud-clast conglomerate and sandstones have been identified above the Ross Slide in the Bridges of Ross outcrop (Eire grid reference: Q736506). The study site, east of the Bridges of Ross car park, was chosen because the 


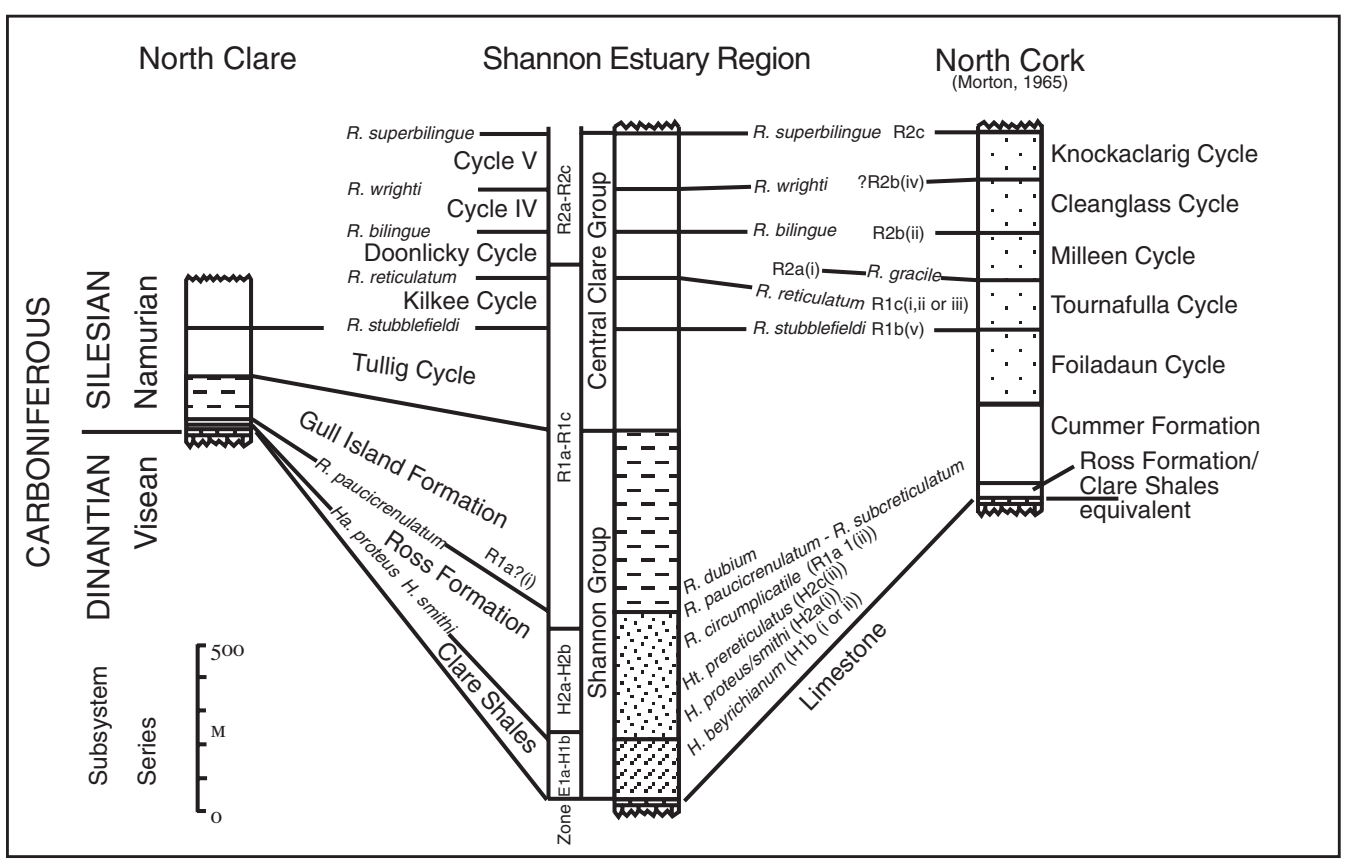

Fig. 2. Stratigraphy of the fill of the Namurian Western Irish Basin, showing the thickening of the Ross Formation in the Shannon Estuary area. (After Collinson et al. 1991)

cliff-faces show a turbidite channel exposing both margins and intrachannel fill (Fig. 4), with no overburden and almost planar top surfaces (Fig. 5). This made GPR data acquisition relatively straightforward. The fill of this channel was described and interpreted (Fig. 4b); it consists of medium and thick-bedded sandstones, thin discontinuous shales and mud-clast conglomerates deposited along inclined bedding surfaces.

Extensive surveying using standard theodolite equipment allowed the reconstruction of the study site surface. A 3-D surface model of the outcrop was generated in Roxar RMS software (Fig. 6). Survey data from the terrace edges were used to generate synthetic 'faults', which 'offset' the topographic surface, in order to avoid smoothing in the generation of the surface grid. The surface top was subdivided into ten terraces $\left(T^{1-10}\right)$ for easier identification (marked on Fig. 6). Note that $T^{l}$ includes more than one surface, but this area is not part of the GPR survey site.

The west cliff-face shown in Figure 4 was also extensively surveyed. Three sedimentary logs, acquired at locations VRP1 and VRP2 and one location on the eastern cliff-face, were converted into pseudo-well logs, which have been incorporated into the models (represented by the subvertical columns in Fig. 6).

\section{GPR acquisition and testing}

An intensive week of GPR acquisition was undertaken at the Bridges of Ross study site in September 2000. A series of in-lines and cross-lines (Fig. 7) were acquired using the fixed-offset profiling technique across the top surface of the study site, using pulseEKKO 1000 GPR equipment. Survey lines were often reprofiled using a variety of antenna frequencies (Table 1 lists the parameters used for profiling). Profiles were also surveyed, for later static corrections to be applied during processing, to account for surface rugosity.

Extensive testing was undertaken before the main survey in order to choose the optimal dominant frequency antennae to image the turbidite channel base, channel margin and the intrachannel fill. Figure 8 shows fixed-offset profiles acquired on the same line (I6) using: (1) $225 \mathrm{MHz}$, and (2) $450 \mathrm{MHz}$ dominant frequency antennae. Note that statics adjustments have not been applied on these sections (the obvious distortions at $\sim 5.5 \mathrm{~m}$ occur as a result of crossing a terrace edge). Figure $8 b$ shows the $450 \mathrm{MHz}$ frequency antennae profile, which images the shallow subsurface (0-25 ns) much better than the same area profiled by the $225 \mathrm{MHz}$ frequency antennae. The $110 \mathrm{MHz}$ dominant frequency antennae profile, not shown here, 


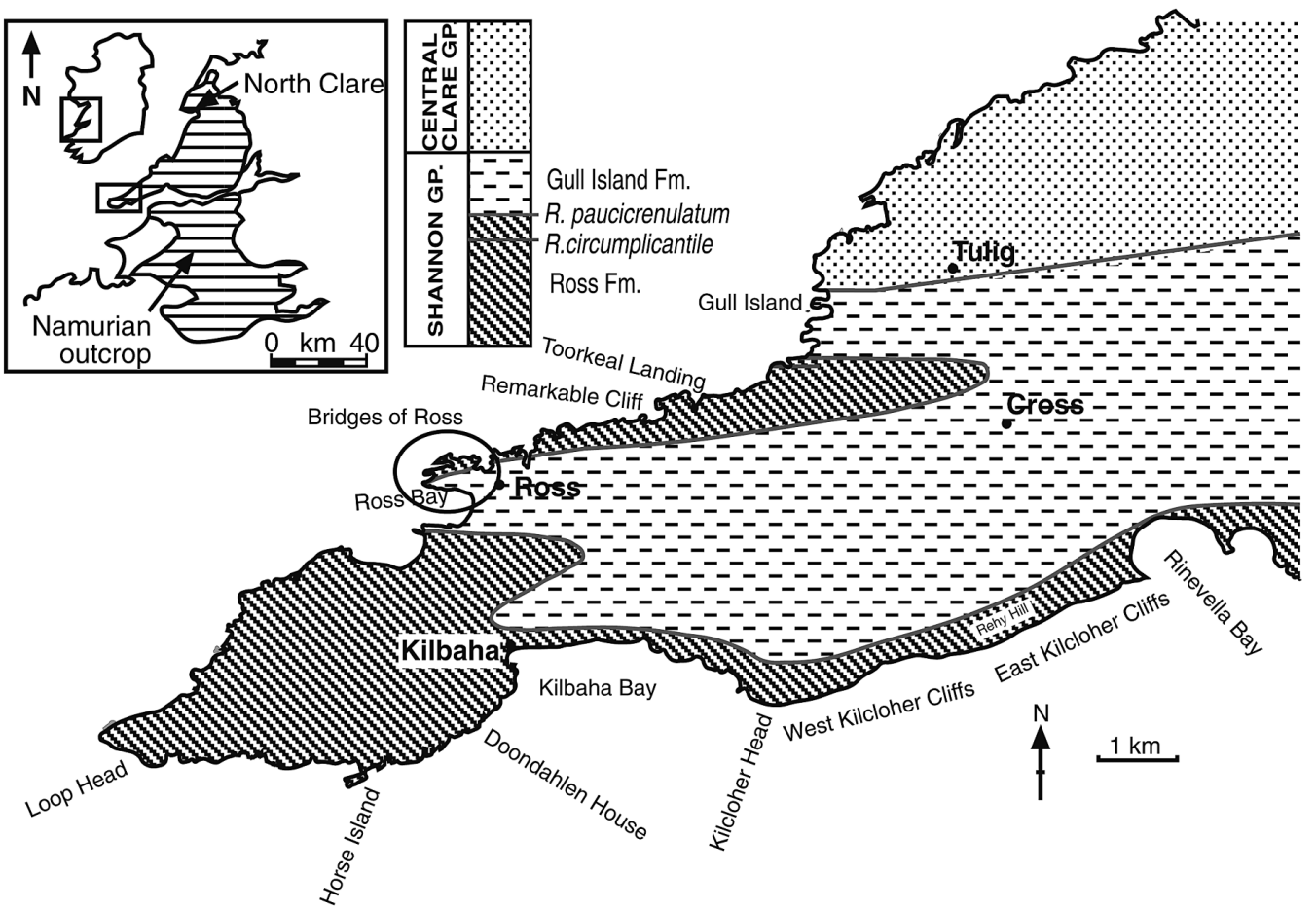

Fig. 3. Location map of the study area (circled), with (inset) location of the Loop Head peninsula and the outcropping of the Shannon Group and overlying Central Clare Group. The outcrop pattern reflects the ENE-WSW-oriented Variscan structures. The extent of the R. circumplicantile marine band (used for dating purposes) is uncertain.

successfully imaged the channel base, but did not resolve reflection events in intrachannel areas. Fixed-offset profiles using $225 \mathrm{MHz}$ antennae were utilized over all the profile lines shown in Figure 7. Although these profiles imaged the whole channel (see Fig. 9 for example), intrachannel-fill reflection events were not resolvable. A smaller profiling survey was then undertaken over the southwestern side of the survey area using $450 \mathrm{MHz}$ dominant frequency antennae (shown as bold lines on Fig. 7).

The frequency spectra of the reflection events recorded with different frequency antennae in the test lines were also analysed (Fig. 8c). The $110 \mathrm{MHz}$ and $225 \mathrm{MHz}$ antennae show comparatively narrow bandwidths, although they have the greatest penetration depths. The $450 \mathrm{MHz}$ antennae show by far the widest bandwidth, which should provide the best profiles. Ideally a combination of $225 \mathrm{MHz}$ and $450 \mathrm{MHz}$ dominant frequency profiling should give the clearest picture of the shallow subsurface. Testing all available frequencies on a study site before a full survey commences was shown here to be critical in order to gain the best possible data.

\section{Techniques to calculate site velocities}

\section{Common mid-point (CMP) gathers}

As is the usual practice when acquiring GPR data, common mid-point (CMP) gathers were acquired on a test line (I1), using $110 \mathrm{MHz}$ and $225 \mathrm{MHz}$ frequency antennae. During subsequent processing, interval velocities between reflection events were calculated, the average velocities derived from the two CMPs being $0.15 \mathrm{~m} \mathrm{~ns}^{-1}$ (eight samples with a reflection coefficient [RC] of 0.99 ) and $0.14 \mathrm{~m} \mathrm{~ns}^{-1}$ (five samples, with an R2 of 0.97) for the $110 \mathrm{MHz}$ and $225 \mathrm{MHz}$ frequency antennae respectively. This variation in velocities is interesting and is discussed further in Pringle et al. (2003).

\section{Vertical radar profiles (VRPs)}

Subsurface GPR reflection events need to be correlated with observed geology. Research at HeriotWatt University has adapted the vertical seismic profiling (VSP) technique to acquire vertical radar profiles (VRPs) (see Pringle et al. 2003 for a more detailed description). The transmitter and recorder 

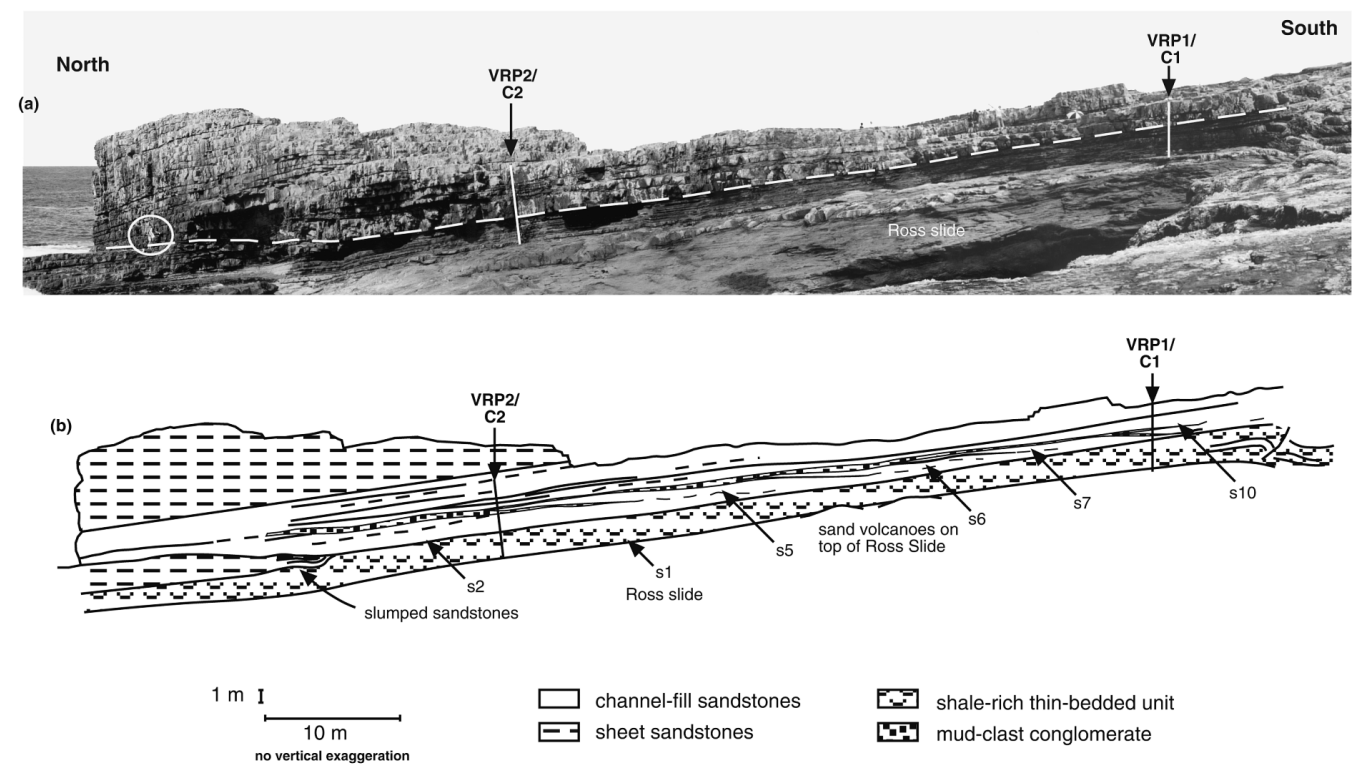

Fig. 4. (a) Photomosaic of the western cliff-face at the Bridges of Ross study site (circled figure for scale), showing a turbidite channel with erosive base (marked by the dashed line). VRP1 and VRP2 locations are marked, as are the end-points of cross-lines C2 and C1. (b) Sketch of architecture shown in (a), section oriented slightly oblique to palaeocurrent direction (northeast). Intrachannel fill of south-dipping sandstones and mud-clast conglomerates are shown. Possible correlations with GPR interpreted horizons (s1, s2, s5, s6, s7 and s10) are marked (compare GPR profiles in Figs 10-13).

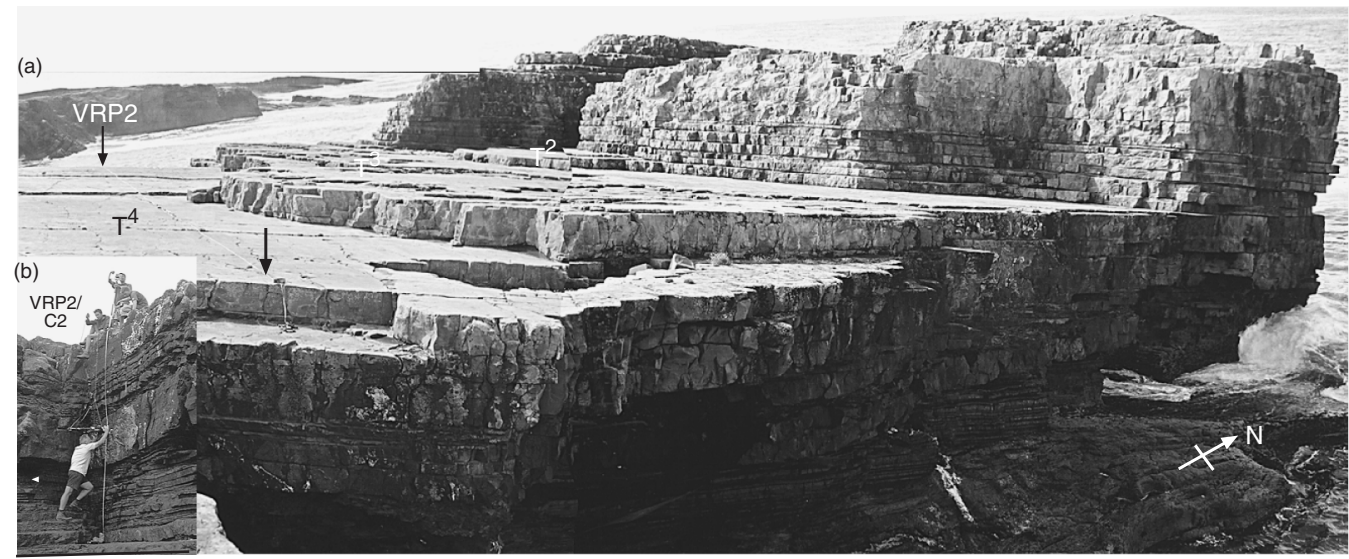

Fig. 5. (a) View of the top surface of the Bridges of Ross study site, looking northwestward. The planar surface (although interrupted by terraces) was ideal for GPR profile acquisition. The top surface has been subdivided $\left(T^{1-9}\right)$ for easier identification. The C2 cross-line can be seen (white tape). (b) Photograph of the VRP2 location on the west cliff.

are left at the cliff-top, with the receiver being moved progressively down the cliff-face at a constant sample interval. After processing, the upgoing wavefield is displayed within time/distance axes. Reflection events can then be tied to observed sedimentological horizons on the cliff-face and extended into the subsurface data. Unfortunately the first VRP was corrupted, but the VRP acquired at location VRP2 (1.86 m long) shows a strong direct ground-wave, with an overall average velocity of $0.23 \mathrm{~m} \mathrm{~ns}^{-1}$ being calculated from the 95 first-arrival picks. Small velocity changes are 


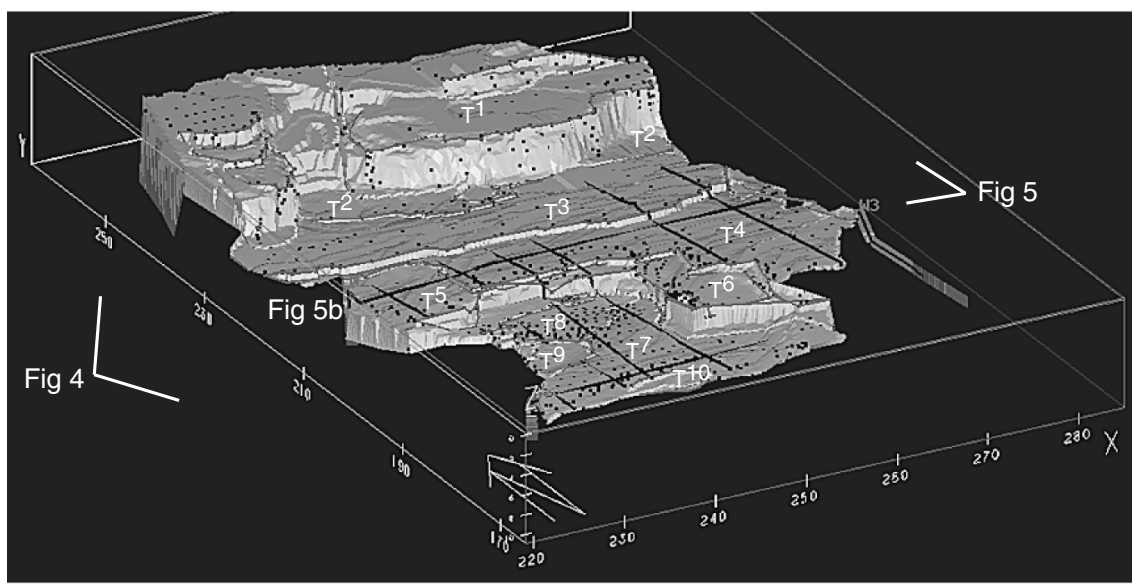

Fig. 6. Standard surveying techniques (using theodolite equipment) of the study-site outcrop surface produced a set of coordinate points (dots). These data were used to grid a 3-D surface using Roxar RMS software. The terrace edges were modelled as 'faults' to help in the surface gridding process. The terraces are numbered $\left(T^{1-10}\right)$ for identification on profiles. $225 \mathrm{MHz}$ GPR profile locations are shown (black lines). Three sedimentary logs acquired on cliff-faces were imported as pseudo-well logs (columns).

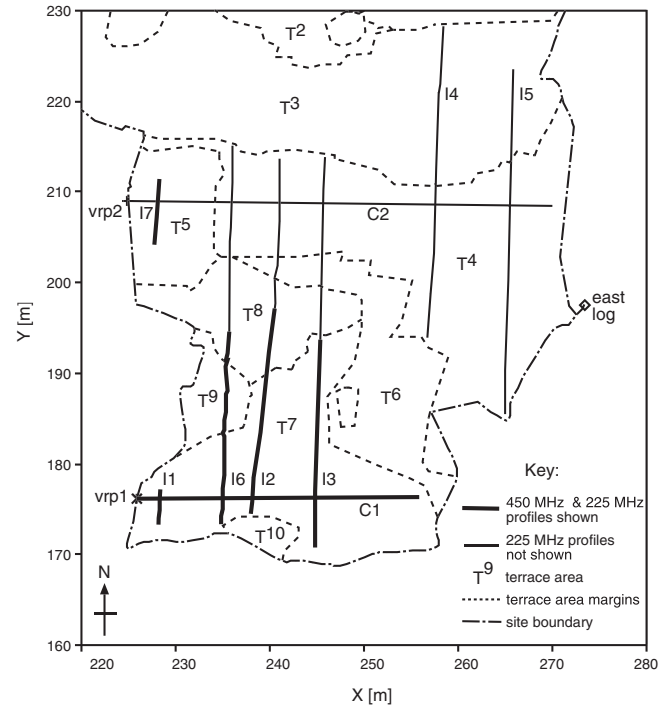

Fig. 7. Plan-view map of the study area showing the location of the GPR profiles, VRP profiles and sedimentary log locations. GPR profiles included in subsequent figures are shown as bold solid lines. Dashed lines show the terraces $\left(T^{1-10}\right)$; compare with Figure 6. Note $450 \mathrm{MHz}$ frequency data part-profiles lines I2, I3 and I6, i.e. do not extend to $T^{4}$ or $T^{6}$ areas.

observed at reflecting horizons, which may reflect lithological velocity variations (for further discussion see Pringle et al. 2003). The average velocity was used to correct elevation statics on subsequent fixed-offset profiles, as well as converting the 2-D profiles from time to depth.

\section{GPR fixed-offset profile results and interpretation}

Once the fixed-offset profiles had been processed using standard seismic techniques (Pringle et al. 2003, table 3), reflection events could be interpreted as mappable horizons. In-line I7, nearest the west cliff-face at the northern end of the study site, was only profiled using $225 \mathrm{MHz}$ frequency antennae (Fig. 9a). However, the northern channel margin observed in Figure 4 could be found to correlate with reflection events on the radar in-line (Fig. 9b). The I1 in-line (used for initial frequency tests) was profiled using all frequencies, and reflection events were tied to nearby vertical cliffedges. The $450 \mathrm{MHz}$ frequency profile is shown in Figure 10a. Interpretation of this in-line (Fig. 10b) shows dipping bedforms, which can be correlated with observed sedimentary horizons (Fig. 10c). This profile gave us some confidence that the highfrequency GPR profiles were imaging subsurface reflection events which could be correlated to observed sedimentary horizons in cliff-faces.

Westward of in-lines I7 and I1 are in-lines I2, I6 and I3 (see Fig. 7 for location). These in-lines were profiled with $450 \mathrm{MHz}$ frequency antennae (Figs 11-13). Figure 11 shows the statically corrected in-line I6. The mud-clast conglomerate layer exposed on terrace $T^{9}$ can be correlated with our interpreted horizon s10, which extends below both the $T^{7}$ and $T^{8}$ terraces. 
Table 1. GPR F-O, CMP and VRP profile parameters*

\begin{tabular}{|c|c|c|c|c|c|c|c|c|}
\hline $\begin{array}{l}\text { Instrument } \\
\text { system }\end{array}$ & $\begin{array}{c}\text { Antenna } \\
\text { frequency } \\
(\mathrm{MHz})\end{array}$ & $\begin{array}{c}\text { Acquisition } \\
\text { technique }\end{array}$ & $\begin{array}{c}\text { Antennae } \\
\text { separation } \\
\text { (m) }\end{array}$ & $\begin{array}{c}\text { Trace } \\
\text { sample } \\
\text { spacing } \\
\text { (m) }\end{array}$ & $\begin{array}{c}\text { Time } \\
\text { window } \\
\text { (ns) }\end{array}$ & $\begin{array}{c}\text { Window } \\
\text { range } \\
(\mathrm{m})\end{array}$ & Stacks & $\begin{array}{c}\text { Sampling } \\
\text { interval } \\
\text { (ps) }\end{array}$ \\
\hline PE100 & 50 & F-O profile & 2 & 0.2 & 300 & 15 & 512 & 800 \\
\hline PE100 & 100 & F-O profile & 1 & 0.2 & 200 & 10 & 512 & 800 \\
\hline PE100 & 200 & F-O profile & 0.5 & 0.1 & 200 & 10 & 512 & 800 \\
\hline PE1000 & 225 & F-O profile & 0.5 & 0.1 & 20 & 1 & 512 & 300 \\
\hline PE1000 & 450 & F-O profile & 0.25 & 0.05 & 20 & 1 & 512 & 100 \\
\hline PE100 & 100 & CMP & - & 0.1 & 300 & 15 & 256 & 800 \\
\hline PE1000 & 225 & CMP & - & 0.05 & 100 & 5 & 128 & 300 \\
\hline PE1000 & 225 & VRP & - & 0.02 & 180 & 9 & 512 & 300 \\
\hline
\end{tabular}

F-O, fixed offset

CMP, common mid-point

VRP, vertical radar profiling

*These parameters were used unless otherwise stated in the text.

From the interpreted surfaces (s1-s10) shown in Figures $11-13$, it is clear that the southerly channel margin (represented by s8 surface) is migrating northward and is oriented SW-NE. This reflects the average palaeocurrent direction observed in this study and by other authors (Elliott 2000a). Interpreted horizons clearly show intrachannel dipping horizons (e.g. s5, s6 and s7). These interpreted surfaces have been corrected to depositional dip (flattened on $T^{7}$ surface) and correlated between inlines. Time values were converted to depth, and contour plots of surfaces s5, s6 and s7 were generated (Fig. 14). Interpreted surfaces s6 (Fig. 14b) and s7 (Fig. 14c) can be clearly seen increasing in dip and eroding the interpreted surface s5 (Fig. 14a). From this contour information, dip and strikes were calculated: $\mathrm{s} 5$ dips $1.4^{\circ}$ toward $090^{\circ}$; s6 dips $3^{\circ}$ toward $151^{\circ}$; and s7 dips $3.7^{\circ}$ toward $137^{\circ}$. The shallow s5 surface is dipping oblique to channel orientation, whereas the steeper s6 and s7 surfaces are approximately parallel to channel orientation. Contouring the surfaces produced from correlating interpreted horizons from the GPR profiles was important because it shows the 3-D geometry of the intrachannel stratal patterns.

\section{3-D model building}

Three volumetric 3-D digital models of the study site were produced, incorporating varying degrees of detail and input data. The simplest model was created from surveyed data of the outcrop surface, sedimentary log information and surfaces digitized from the west cliff-face (Fig. 15a). Resulting horizons, however, were planar, as data was simply extrapolated from the 2-D cliff-face. A more detailed model was produced, incorporating surface data as well as interpreted subsurface horizons imaged on the comparatively low-resolution $225 \mathrm{MHz}$ frequency profiles (Fig. 15b). This was an improvement on the initial model (Fig. 15a) as it provides 3-D volumetric data. Interpreted horizons from the $450 \mathrm{MHz}$ frequency profiles were then incorporated into a third model; the highresolution data shows the interpreted channel margin migrating northward (Fig. 15c).

\section{Further work}

From these models, reservoir models can now be built, probably both deterministically and stochastically, using the surfaces to provide a framework within which 3-D geobodies are stochastically infilled, which honour observed bedding length, width and thickness variations. Fluid-flow simulations can also be undertaken on the resulting models, to see how the 3-D intrachannel-fill heterogeneities, mapped from this GPR survey, affect hydrocarbon sweep efficiency.

A further field season was planned for the summer of 2001, with the aim of acquiring many more $450 \mathrm{MHz}$ frequency profiles right across the study area, at a NW-SE orientation to better capture the channel margins. However, because of the footand-mouth outbreak in the British Isles during that time, this was prohibited. It is hoped that the site can be returned to at a future date and the fieldwork completed.

\section{Conclusions}

The $225 \mathrm{MHz}$ and $450 \mathrm{MHz}$ GPR profiles have imaged the erosive discordant channel base, exposed in the western vertical outcrop face at this study site. In addition, southward-dipping mudclast conglomerate layers observed in the western 

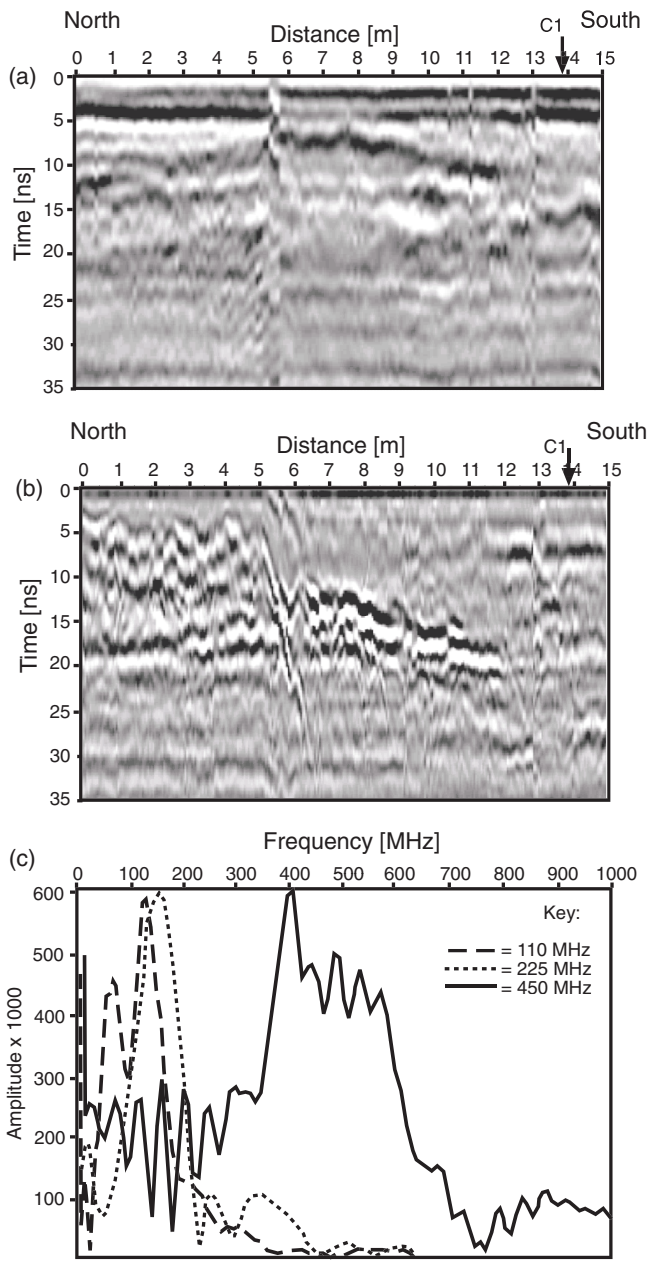

Fig. 8. Comparison of profiles acquired on I6 in-line, using (a) $225 \mathrm{MHz}$ and (b) $450 \mathrm{MHz}$ frequency antennae. Improved resolution in the top $15 \mathrm{~ns}$ can be observed in the $450 \mathrm{MHz}$ section. $\mathrm{C} 1$ cross-line location is marked. Note statics corrections have not been applied here, and terrace-edge distortions are clearly observed (at $\sim 5.5 \mathrm{~m}$ ) on both sections. (c) Dominant GPR frequency spectra produced by $110 \mathrm{MHz}, 225 \mathrm{MHz}$ and $450 \mathrm{MHz}$ antennae, derived on the same section of line I1. $110 \mathrm{MHz}$ and $225 \mathrm{MHz}$ results show a typically narrow band. $450 \mathrm{MHz}$ antennae results are much more broadband, providing the most useful information.

cliff-face could also be resolved using higher frequency (450 MHz) GPR antennae. The southern channel margin can be seen to be oriented NW$\mathrm{SE}$, reflecting the palaeocurrrent trend, and can be shown to migrate northwards. Dip and strike measurements of inclined reflectors in intrachannel fill have been calculated from the 3-D subsurface information. If the $450 \mathrm{MHz}$ GPR antennae are
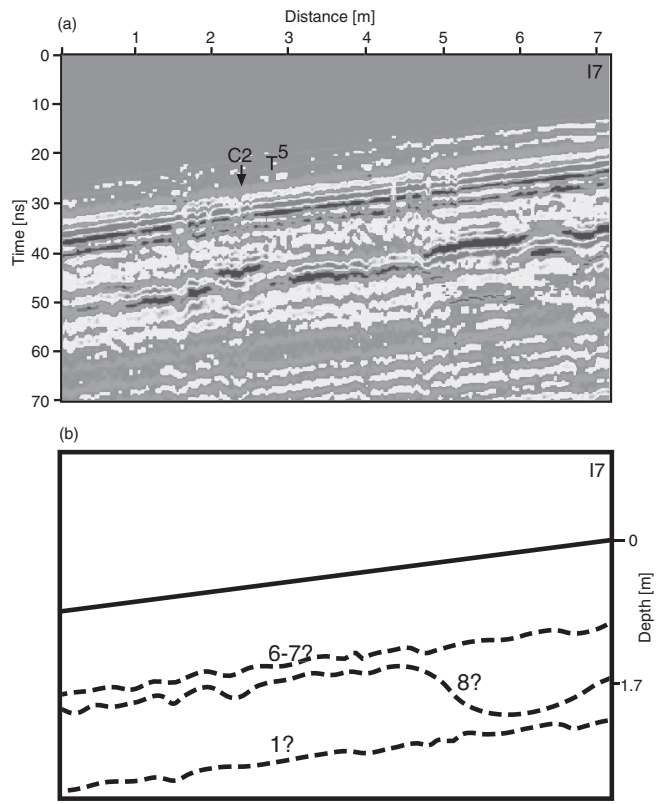

Fig. 9. (a) Statically corrected I7 in-line profiled using $225 \mathrm{MHz}$ frequency antennae, with (b) subsequent interpretation. Trace-sample spacing was $10 \mathrm{~cm}$. The incised surface (s8) correlates with the northern channel margin, exposed in the vertical western outcrop face of the survey area, m west of this in-line (see Fig. $4 a$ ).

used to acquire a 3-D reflection survey, the turbidite channel fill will be fully characterized in 3D. Integration of sedimentary data, surveying data, GPR profiles and interpreted horizons were used to create 3-D digital models of the study site, with varying detail, depending on the input data.

Presurvey testing of available antennae frequencies to optimize subsequent surveys was shown to be critical to gain the best subsurface data. Applying elevation statics, even on relatively planar, ancient sedimentary study sites was shown to be important in correctly interpreting GPR reflection events.

The authors wish to thank reviewers T. Elliott and D. Stow for greatly improving this manuscript. The authors gratefully acknowledge the support of their respective projects at Heriot-Watt University: the Genetic Units Project, GEOscience and Testing for the Identification of Petroleum Elements (GEOTIPE), the Geophysics Used for the Management of Petroleum Assets Project (GUMPA) and their respective sponsor companies. The Dynamic Geoscience Laboratory, part-funded by Fairfield Industries and based at Heriot-Watt University, is also acknowledged. We should also like to thank B. Morgan, D. Tatum and D. Stanbrook for field assistance. A. Brown and P. Fenning of Earth Science Systems Ltd are acknowledged for GPR support. Two American Associ- 

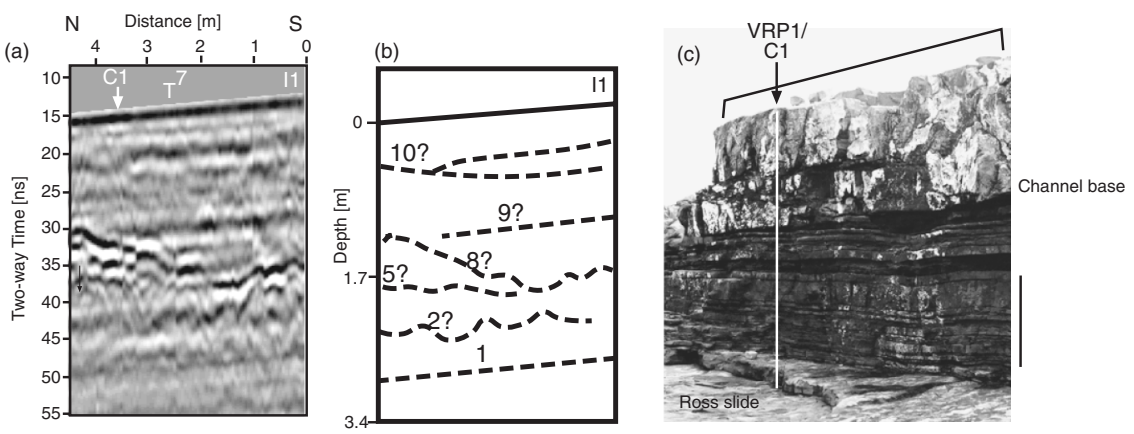

Fig. 10. (a) Statically corrected I1 in-line partly profiled using $450 \mathrm{MHz}$ frequency antennae, with (b) subsequent interpretation. Trace-sample spacing was $5 \mathrm{~cm}$. Interpreted horizons are numbered. Comparison with nearby outcrop cliff-face (c) shows interpreted horizon 8 may correspond to southerly dipping mud clast conglomeratic layers.

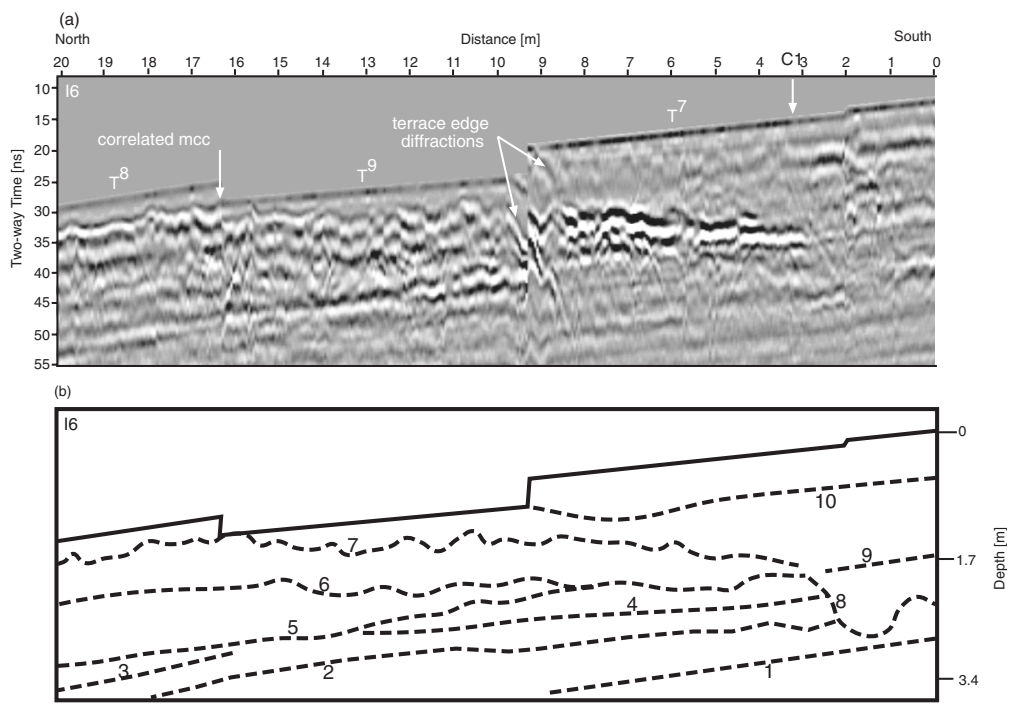

Fig. 11. (a) Statically corrected I6 in-line, partly profiled using $450 \mathrm{MHz}$ frequency antennae, with (b) subsequent interpretation. Trace-sample spacing was $5 \mathrm{~cm}$. Interpreted horizons are numbered. Terrace edges have caused diffractions (marked), illustrating the importance of statically correcting profiles. An exposed mud-clast conglomerate layer in $T^{9}$ can be correlated with a subsurface reflector. Comparisons with Figure $4 a$ show the southerly channel margin is possibly imaged in this profile.

ation of Petroleum Geologists grants-in-aid student awards partially funded the fieldwork. Roxar Ltd are thanked for providing the RMS modelling software and in particular L. Anderson is thanked for technical support. The PC-based VISTA software program, supported by R. Kolesar and M. Galbraith, was supplied by SIS Ltd, Calgary.

\section{References}

Arnot, M. J., Good, T. \& LewIS, J. M. 1997. Photogeological and image-analysis techniques for collection of large-scale outcrop data. Journal of Sedimentary Research, 67, 984-987.
Bryant, I. D., Carr, D., Cirilli, P., Drinkwater, N., McCormick, D., Tilke, P. \& Thurmond, J. 2000. Use of 3D digital analogues as templates in reservoir modelling. Petroleum Geoscience, 6, 195-201.

Collinson, J. D., Martinsen, O., Bakken, D. \& KlosTER, A. 1991. Early fill of the western Irish Namurian Basin: a complex relationship between turbidites and deltas. Basin Research, 3, 223-242.

ElliotT, T. 2000a. Depositional architecture of a sand-rich, channelised turbidite system: the Upper Carboniferous Ross Sandstone Formation, Western Ireland. Proceedings of the Gulf Coast Section of the Society of Economic Palaeontologists and Mineralogists Foundation 20th Annual Conference of Deep-Water Reservoirs of the World, 3-6 December, Houston, USA, 342-373. 


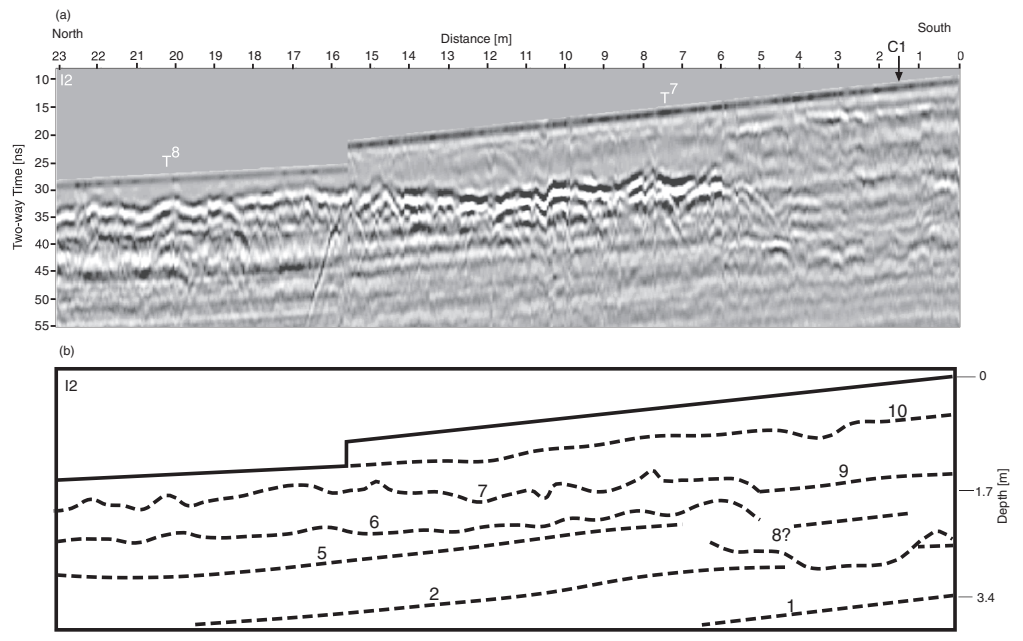

Fig. 12. (a) Statically corrected $\mathrm{I} 2$ in-line partly profiled using $450 \mathrm{MHz}$ frequency antennae, with (b) subsequent interpretation. Trace-sample spacing was $5 \mathrm{~cm}$. Interpreted horizons are numbered (cf. Fig. 11).

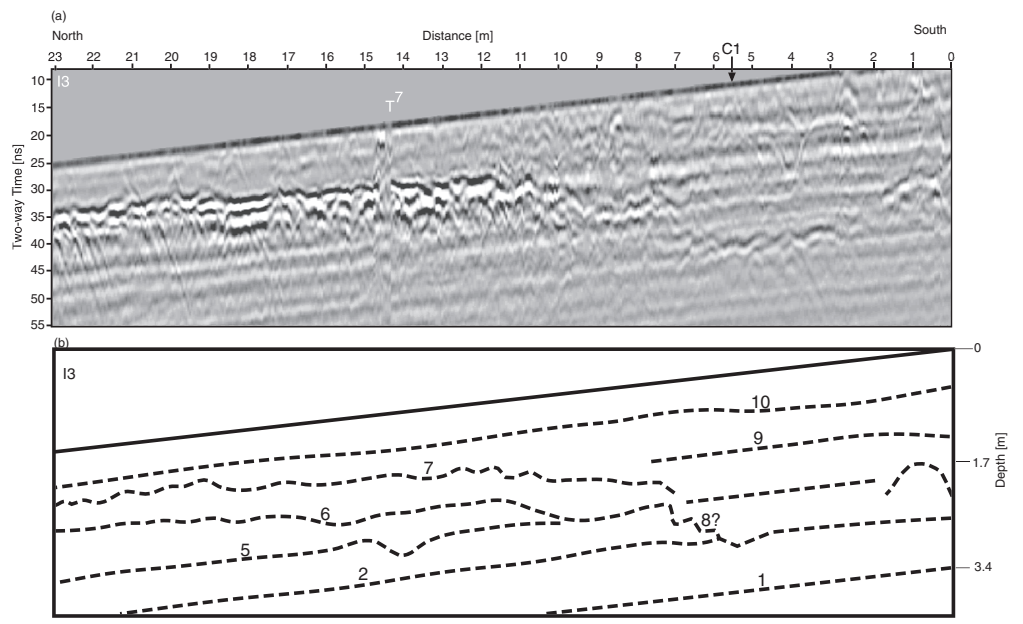

Fig. 13. (a) Statically corrected I3 in-line partly profiled using $450 \mathrm{MHz}$ frequency antennae, with (b) subsequent interpretation. Trace-sample spacing was $5 \mathrm{~cm}$. Interpreted horizons are numbered (cf. Fig. 12).

Elliott, T. 2000 $b$. Megaflute erosion surfaces and the initiation of turbidite channels. Geology, 28, 119-122.

GeEhan, G. 1993. The use of outcrop data and heterogeneity modelling in development planning. In: Eschard, R. \& Doligez, B. (eds) Subsurface Reservoir Characterization from Outcrop Observations. Editions Technip, Paris, 3-64.

Geehan, G. \& Underwood, J. 1993. The use of length distributions in geological modelling. In: FLINT, S. S. \& BRYAnT, I. D. (eds) The Geological Modelling of Hydrocarbon Reservoirs and Outcrop Analogues. International Association of Sedimentologists Special Publications, 15, 205-212.

Hodson, F. 1954. The beds above the Carboniferous Limestone in north-west County Clare, Eire. Quarterly
Journal of the Geological Society of London, 109, 259-283.

Joseph, P., Babonneau, N. et aL. 2000. The Annot sandstone outcrops (French Alps): architecture description as input for quantification and 3D reservoir modelling. Proceedings of the Gulf Coast Section of the Society of Economic Palaeontologists and Mineralogists Foundation 15th Annual Research Conference on Submarine Fans and Turbidite Systems, 4-7 December, 422-449.

Kolla, V., Bourges, P., Urruty, J. \& Safa, P. 2001. Evolution of deep-water Tertiary sinuous channels offshore Angola (west Africa) and implications for reservoir architecture. Bulletin of the American Association of Petroleum Geoscientists, 85, 1373-1405. 
(a)

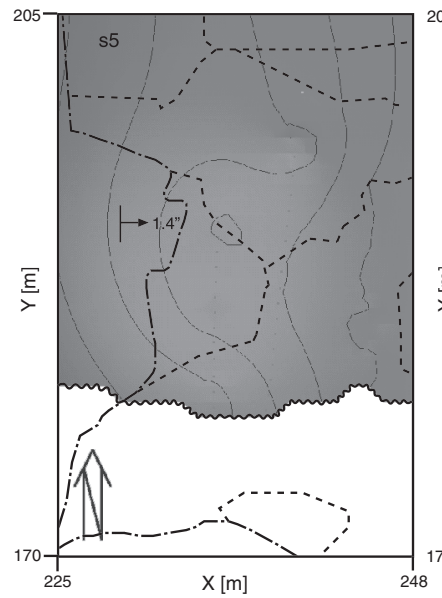

(b)

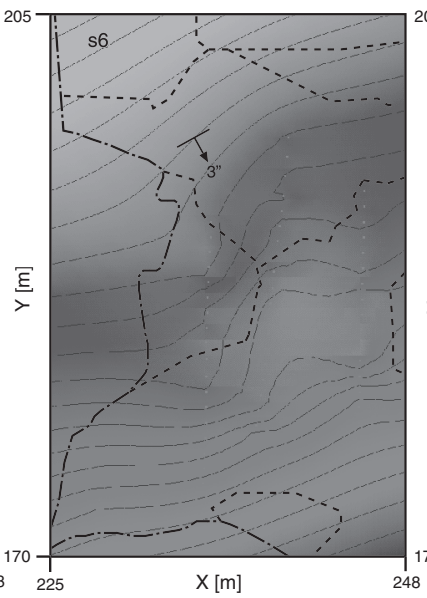

(c)

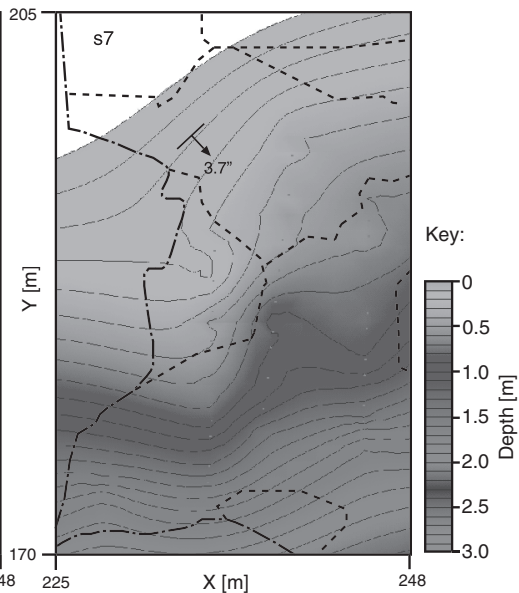

Fig. 14. Interpreted horizons (a) s5, (b) s6, and (c) s7 on $450 \mathrm{MHz}$ profile in-lines I1, I2, I3 and I6 have been picked, correlated and the data have been rotated back to original sedimentary dip. From the picks (dots), interpreted surfaces have been generated, s5 (bottom surface), s6 (grid) and s7 (top), in Roxar RMS software. Surfaces have then been contoured, allowing strike and dips to be calculated for the three horizons.

Pickering, K. T., Colman, J. M. et AL. 1986. A high sinuosity, laterally migrating submarine fan channellevee-overbank: results from DSDP Leg 96 on the Mississippi Fan, Gulf of Mexico. Marine and Petroleum Geology, 3-18.

Piper, D. J. W., \& Normark, W. R. 1983. Turbidite depositional patterns and flow characteristics, Navy submarine fan, California Borderland. Sedimentology, 30, 681-694.

Pringle, J. K., Westerman A. R., Clark J. D., Guest J. A., Ferguson R. J. \& Gardiner A.R. 2003. The use of vertical radar profiling (VRP) in GPR surveys of ancient sedimentary strata. In: BRISTOW, C. S. \& JoL, H. (eds) GPR in Sediments. Geological Society, London, Special Publications, 211, 225-246.

Stephen, K. D., Clark, J. D. \& Gardiner, A. R. 2001. Outcrop-based stochastic modelling of turbidite amal- gamation and its effects on hydrocarbon recovery. Petroleum Geoscience, 7, 163-172.

Visser, C. A. \& Chessa, A. G. 2000. Estimation of length distribution from outcrop datasets - application to the Upper Permian Cutler Formation, Utah. Petroleum Geoscience, 6, 29-36.

Weber, K. J., 1993. The use of 3-D seismic in reservoir geological modelling. In: FLINT, S. S. \& BRYANT, I. D. (eds) The Geological Modelling of Hydrocarbon Reservoirs and Outcrop Analogues. International Association of Sedimentologists Special Publications, 15, 181-188.

Xu, X., Aiken, C. L., Bhattacharya, J. P., Corbeanu, R. M., Nielsen, K.C., McMechan, G. A. \& AbdelsaLAM M. G. 2000. Creating virtual 3-D outcrop. Leading Edge, February, 197-202. 
(a)

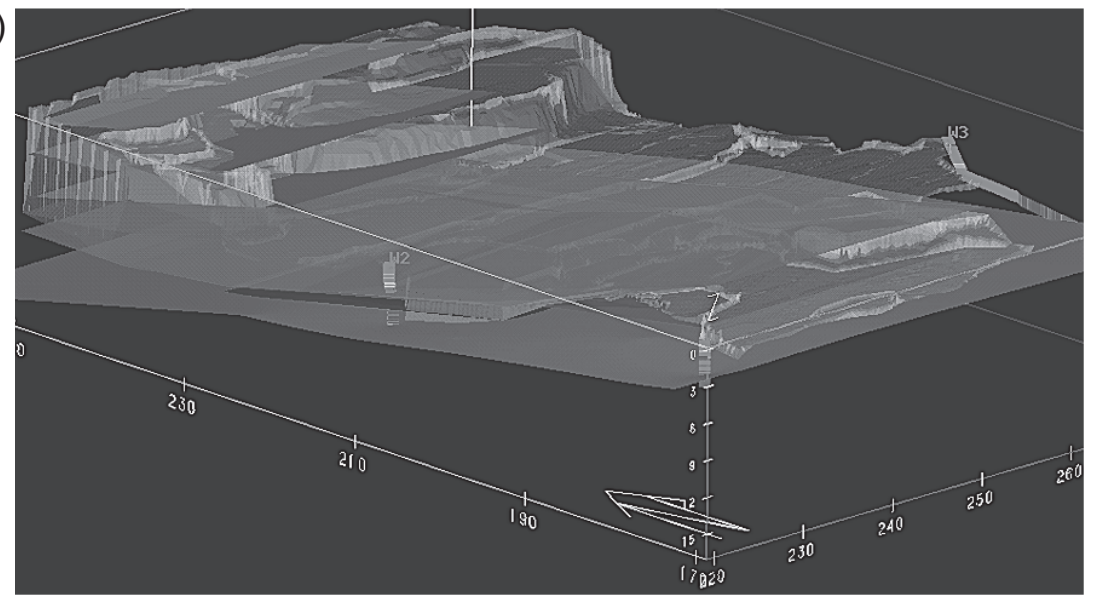

(b)

(c)
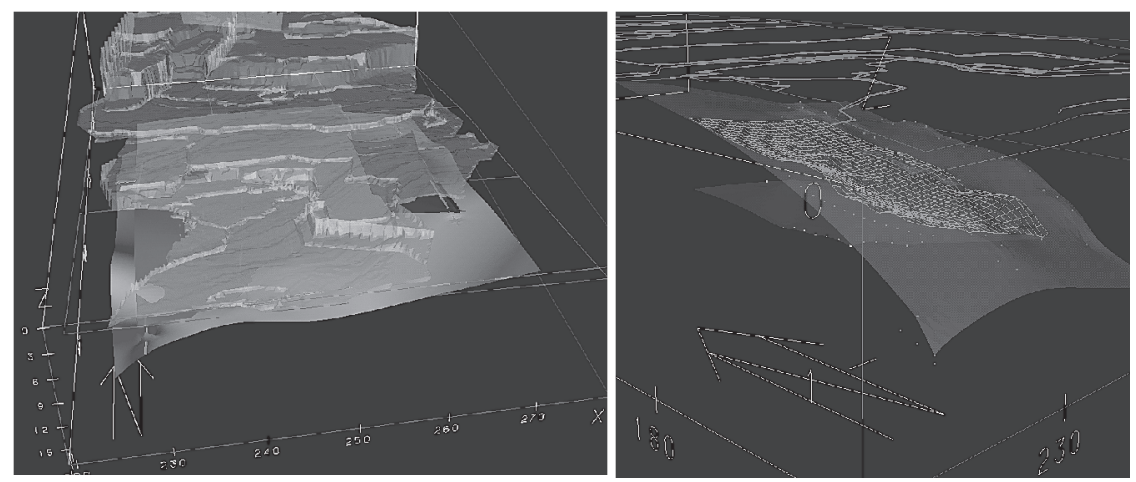

Fig. 15. 3-D digital models of the Bridges of Ross study site, produced in Roxar RMS software. (a) Surface data of the outcrop surface has been used to create this model. Sedimentary log information has been incorporated as pseudowell logs and used to correlate sedimentary horizons. (b) Interpreted horizons from $225 \mathrm{MHz}$ frequency profiles have been added to the previous model. The contoured surface is interpreted as the channel base. (c) Interpreted horizons from $450 \mathrm{MHz}$ frequency profiles have been incorporated into the surface model, showing the interpreted southerly channel margin migrating northwards. 